\title{
Crustal wide-angle reflection imaging along Lianxian-Gangkou profile in Guangdong province, China*
}

\author{
Zhongjie Zhang * Bing Zhao Xi Zhang and Jiwen Teng \\ State Key Laboratory of Lithospheric Evolution, Institute of Geology and Geophysics, \\ Chinese Academy of Sciences, Beijing 100029, China
}

\begin{abstract}
A $400 \mathrm{~km}$-long wide-angle seismic experiment along Lianxian-Gangkou profile in South China was carried out to study contact relationship between southeast continental margin of Yangtze block and northwest continental margin of Cathaysia block. We reconstructed crustal wide-angle reflection structure by the depth-domain pre-stack migration and the crustal velocity model constructed from the traveltime fitting. The wide-angle reflection section shows different reflection (from crystalline basement and Moho) pattern beneath the Yangtze and Cathaysia blocks, and suggests the Wuchuan-Sihui fault is the boundary between them. A cluster of well-developed reflections on Moho and in its underlying topmost mantle probably comes from alternative thin layers, which may be seismic signature of strong interaction between crust and mantle in the tectonic environment of lithosphere extension.
\end{abstract}

Key words: Yangtze block; Cathaysia block; seismic sounding; seismic wide-angle reflection; Moho reflection clustering; crust/mantle interaction

CLC number: P315.63 Document code: A

\section{Introduction}

The South China tectonic regime is consisted of three main elements: the southeast continental margin of Yangtze block, the northwest continental margin of Cathaysia and the boundary of South China suture zone (SCSZ) between Yangtze and Cathaysia blocks (Figure 1) (Zhang et al, 1984; Guangdong Bureau of Geology and Mineral Resources, 1988; Angelier, 1990; Hou and Li, 1993).

The South China continent, located at the continental margin of western Pacific ocean, endures the subduction of western Pacific plate. Since Grabau (1924) first used Cathaysia to describe the geology of southeastern China and part of the coastal region of west $\mathrm{Pa}$ cific, it has been about 80 years dispute on regional tectonics, and much of the disputation has been focused on whether or not "Cathaysia" really exists, its distribution and tectonic evolution (Huang, 1980; Guo et al, 1983; Yang et al, 1986; Yin and Nie, 1993; Zhang et al, 1994).

\footnotetext{
* Received 17 April 2009; accepted in revised form 9 June 2009; published 10 August 2009.

• Corresponding author. e-mail: zhangzj@mail.iggcas.ac.cn
}

Several authors suggested that such an old continental mass is present (Shui, 1988; Jahn et al, 1990; Wang and Liu, 1992), but its distribution remains controversial (Shui, 1988; Ren et al, 1990). In recent twenty years, several tectonic models have been postulated to account for the Mesozoic tectonic evolution of the South China block (Jahn et al, 1986, 1990; Rodgers, 1989; Rowley et al, 1989; Hsü et al, 1990; Charvet et al, 1996; Li et al, 2000; Zhou and Li, 2000; Wang et al, 2003). These models include Andean-type active continental margin (Guo et al, 1983), Alps-type collision belt (Hsü et al, 1988, 1990), and lithospheric subduction (Holloway, 1982; Faure, 1996; Zhou and Li, 2000) with underplating of mafic magma. These models suggest that the tectonic regime is dominantly compressive as the result of either westward subduction of a Mesozoic Pacific plate, or closure of an oceanic basin in the South China block interior (Holloway, 1982; Hsü et al, 1990; Faure, 1996; Zhou and $\mathrm{Li}, 2000)$. Alternative models include wrench faulting (Xu et al, 1993) and continental rifting and extension (Gilder et al, 1996; Li et al, 2000; Wang et al, 2003). These models suggest that intra-continental lithospheric extension and thinning dominant in South China since the early Mesozoic ( $\mathrm{Li}$ et al, 1989; Li et al, 2000; 
Faure, 1996; Gilder et al, 1996; Wang et al, 2003; Li and Li, 2007).

In order to study evolution of the lithosphere in South China and its adjacent sea, Chinese Academy of Sciences (CAS) carried out various research projects involving multidisciplinary integrated studies including geodynamics, marine geology, geochemistry and geophysics experiments between mid-1980s and 1990s (Wei et al, 1990; Li, 1992; Yin et al, 1999; Zhang and Wang, 2007; Zhang et al, 2000, 2005, 2008, 2009). Among these projects, Institute of Geophysics of CAS conducted a deep seismic sounding experiment between Lianxian and Gangkou island in 1990 (Figure 1). Yin et al (1999) and Zhang and Wang (2007) obtained P-wave velocity model along this $400 \mathrm{~km}$-long deep seismic sounding profile, and inferred the crustal boundary between the Yangtze and Cathaysia blocks. Here, based on the crustal P-wave velocity, we reconstruct crustal wide-angle seismic reflection structure from pre-stack migration technique, and present the different pattern beneath the Yangtze and Cathaysia blocks with the boundary of the Wuchuan-Sihui fault between them, and find a series of well-developed reflections of Moho, which probably come from alternative thin layers, and infer the Moho reflections may be seismic signature of strong interaction between crust and mantle in the tectonic environment of lithosphere extension.

\section{Tectonic setting}

Within the tectonic unit of South China, the Yangtze block and the Cathaysia block were consolidated at ca. $970 \mathrm{Ma}$ ( $\mathrm{Li}$ and McCulloch, 1996). The basement rocks of the Yangtze block have an average age of 2.7-2.8 Ga (Qiu et al, 2000) with the oldest of $>3.2 \mathrm{Ga}$. In contrast, basement of the Cathaysia block exhibits paleo-to-Meso-proterozoic and possibly late Archean ages of about $2.5 \mathrm{Ga}$ (Chen and Jahn, 1998; Wang et al, 2003). As shown in Figure 1, late Mesozoic magmatic rocks consisting predominantly of granite and rhyolite with an outcrop area of $95 \%$ spread across a $600 \mathrm{~km}$ belt along the coastline of southeastern China (Wang et al, 2003). Across the continent, volcanic rocks occur mainly in the eastern part of South China suture zone (Figure 1), and the western board of this volcanic belt is located at about $450 \mathrm{~km}$ further away from the eastern one. Igneous rocks in South China fall into three main age groups, i.e., early Yanshanian (180-160 Ma), mid Yanshanian (160-140 Ma) and late Yanshanian (140-97 Ma) (Wang et al, 2003). In some areas, the late Yanshanian group includes rocks as young as ca. $79 \mathrm{Ma}$ (Martin et al, 1994). The early Yanshanian volcanism belongs to a K-rich calc-alkaline series inter-layered with continental or shallow water detrital rocks. Conversely, the late Yanshanian volcanism, of bimodal character, is associated

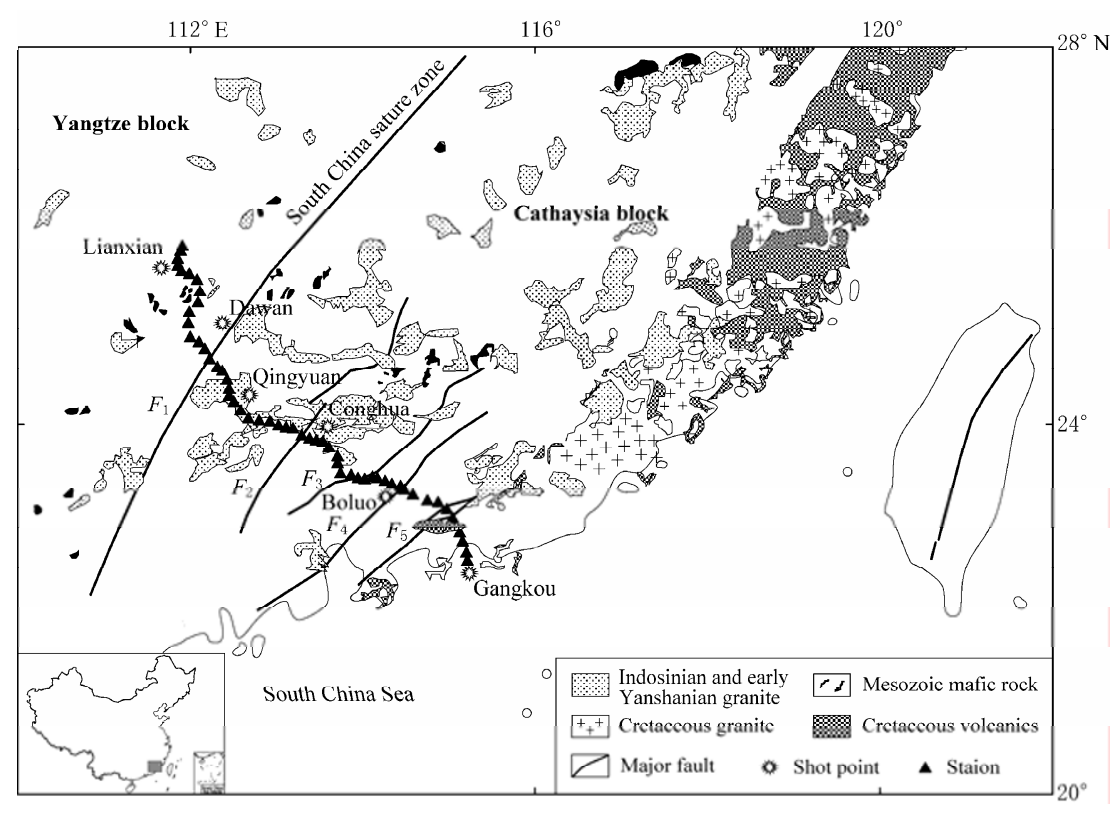

Figure 1 Location map of the Lianxian-Gangkou wide-angle seismic experiment. The major active faults crossed by the seismic profile from northwest to southeast are Wuchuan-Sihui fault $\left(F_{1}\right)$, Enping-Xinfeng fault $\left(F_{2}\right)$, Heyuan-Zengcheng fault $\left(F_{3}\right)$, Zijin-Boluo fault $\left(F_{4}\right)$ and Lianhuashan fault $\left(F_{5}\right)$, same as in Figures 4 and 5. 
with continental red beds along NE-SW trending grabens, indicative of intracontinental rifting. The eruption of volcanic rock increases from the continent to the northern margin of South China Sea (Jahn et al, 1990; Zeng et al, 1997; Zhou and Li, 2000; Wang et al, 2003; Braitenberg et al, 2006), which implies some special lithosphere activities or happened activities in South China.

\section{Deep seismic sounding dataset along the Lianxian-Gangkou profile}

The wide-angle deep seismic sounding experiment (Figure 1) crosses the southern continental margin of Yangtze block, the southeastern continental margin of Cathaysia block and the South China suture zone; its interpretations of crust and upper mantle structure are documented in detail in the previous publications, such as Li (1992), Yin et al (1999) and Zhang and Wang (2007). In order to clarify this study, we summarize the experiment. In this experiment, shots were fired at six sites, Lianxian (LX), Dawan (DW), Qingyuan (QY), Conghua (CH), Boluo (BL) and Gangkou island (GK), and three-component DZSS-1 seismographs were deployed along the profile. The $400-\mathrm{km}-$ long seismic profile with azimuth nearly $\mathrm{N} 30^{\circ} \mathrm{W}$ runs from Lianxian near Hunan province to Gangkou island near Guangzhou city. Along the profile, there are a series of NE faults (Figure 1), i.e., Wuchuan-Sihui fault $\left(F_{1}\right)$, Enping-Xinfeng fault $\left(F_{2}\right)$, Heyuan-Zengcheng fault $\left(F_{3}\right)$, Zijin-Boluo fault $\left(F_{4}\right)$ and Lianhuashan fault $\left(F_{5}\right)$ (Huang, 1980; Wang et al, 2003).

The seismic signals recorded by the seismographs were initially sampled at a rate of $2.5 \mathrm{~ms}$, which guarantees the seismic acquisition of $200 \mathrm{~Hz}$ maximum frequency even though wide-angel seismic profiling is a kind of low frequency seismic survey. The seismic dataset filtered within 1-12 Hz frequency band was interpreted (Yin et al, 1999; Zhang and Wang, 2007). Due to the limit of paper length, we just display two shot gathers of Gangkou island shot (Figure 2a) and Qingyuan shot (Figure $2 \mathrm{~b}$ ) at a reduced time scale using a velocity of 6.0 $\mathrm{km} / \mathrm{s}$, the detail dataset description and phase analyses can be seen in Zhang and Wang (2007).
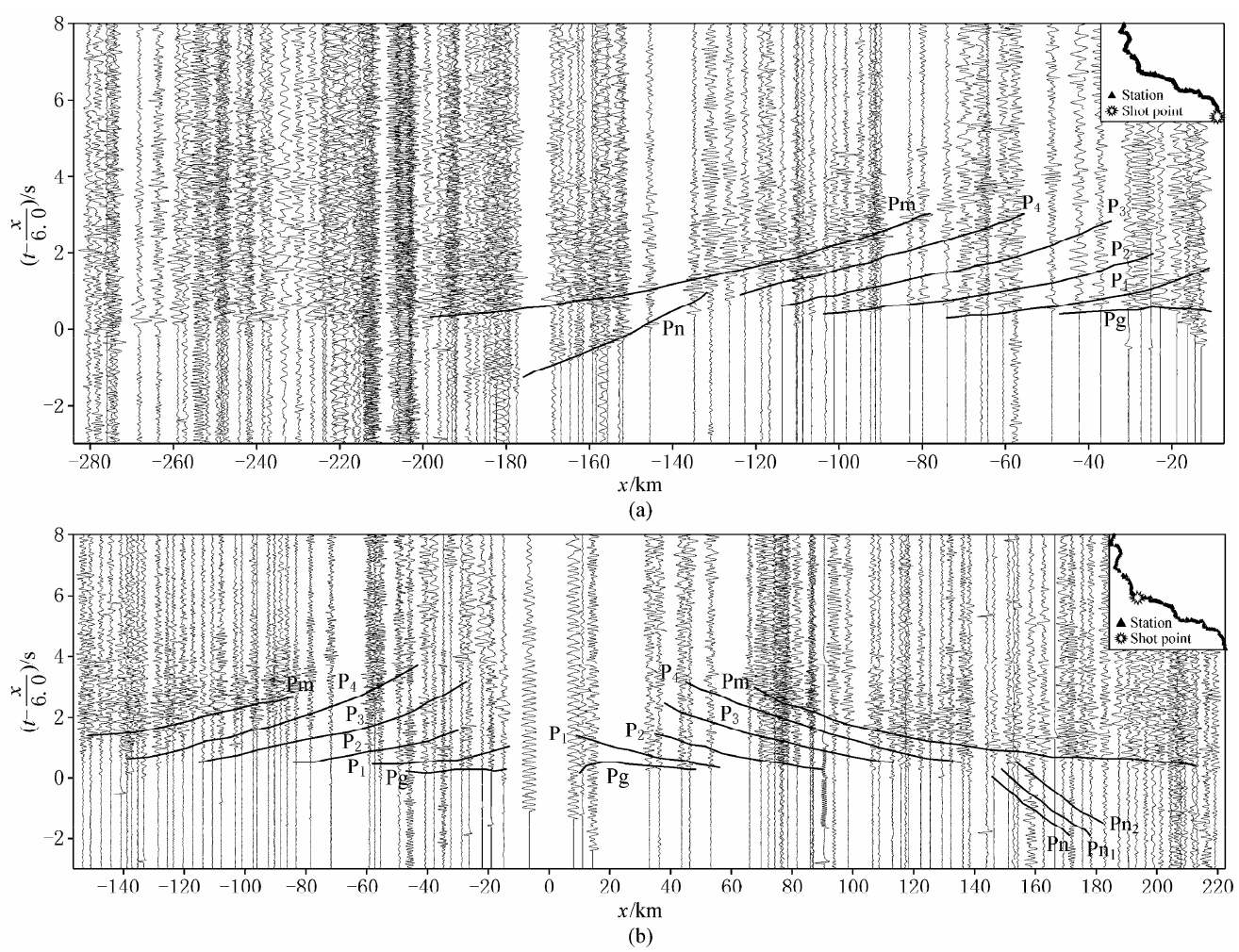

Figure 2 Shot gathers of P-wave vertical component fired at the shot points Gangkou island (a) and Qingyuan (b) after filtering with frequency pass-band of $1-12 \mathrm{~Hz}$. The sections along offset $x$ are reduced using a P-wave reduction velocity of $6.0 \mathrm{~km} / \mathrm{s}$. The thick lines are the computed traveltimes for the crustal model (Yin et al, 1999; Zhang and Wang, 2007). 


\section{Prestack migration to reconstruct crustal wide-angle reflection section}

\subsection{Prestack migration scheme of the wide-angle seismic data}

Phinney and Jurdy (1979), Zhang et al (2000) and Avendonk (2004) used slant stacks of common-source gathers from CMP profiles to back-project reflection energy into the subsurface. A complete image is formed by stacking results for individual gathers. Milkereit (1987) and Zhang et al (2004) divided wide-angle profiles into overlapping, narrow-aperture spatial windows, then used the semblance of the localized slant stacks of those windows to identify coherent arrivals in the time-space domain for inputting a diffraction-stack migration. In this approach, contributions to the migrated image are restricted to input samples, which arrive with the travel times, and ray parameters predicted for diffraction through a velocity model. This improves spatial resolution by suppressing contributions from coherent noise.

Both of the earlier approaches correctly handle diffractions. Structure is brought into focus by summing the contributions from many overlapping source-receiver pairs. Here, we use the depth-domain pre-stack migration and the diffraction-stack migration scheme (Milkereit, 1987; Lafond and Levander, 1995) to reconstruct the fine structure of crust and upper mantle. The pre-stack migration scheme can be summarized as three steps: (1) calculate the traveltime from the imaging point and the source, and the traveltime from the receiver to the imaging point by finite-difference eikonal solver and sum them up, (2) migrate the seismic signal at the summed traveltime (from shot source to receiver) to the imaging point; (3) calculate the seismic resemblance of each imaging point to obtain the whole crustal wide-angle seismic reflection structure.

\subsection{Crustal velocity model used in prestack migration}

The crustal velocity model used in our pre-stack migration of the wide-angle seismic data is shown in Figure 3 for the Lianxian-Gangkou wide-angle seismic profile (Yin et al, 1999; Zhang and Wang, 2007). In order to understand the crustal structure in South China, we summarize the crustal structure along the LianxianGangkou profile from our crustal P-wave velocity models as: (1) the average thickness of the crust is about 34 $\mathrm{km}$ beneath the Yangtze block, thinning gradually from northwest to southeast; (2) the average P-wave velocity for the crust is about $6.3 \mathrm{~km} / \mathrm{s}$; (3) the apparent P-wave velocity of the event $\mathrm{P}_{3}$ is slower than that of the event $\mathrm{P}_{2}$. The latter suggests that there possibly exists one lower velocity layer between the reflectors $\mathrm{P}_{2}$ and $\mathrm{P}_{3}$, even though constrains about the existence of lower velocity layer are not powerful due to limit of the field experiment. In our final model, there is a relatively narrow lower velocity layer with thickness of about $5 \mathrm{~km}$ and with P-wave velocity of $5.8 \mathrm{~km} / \mathrm{s}$.

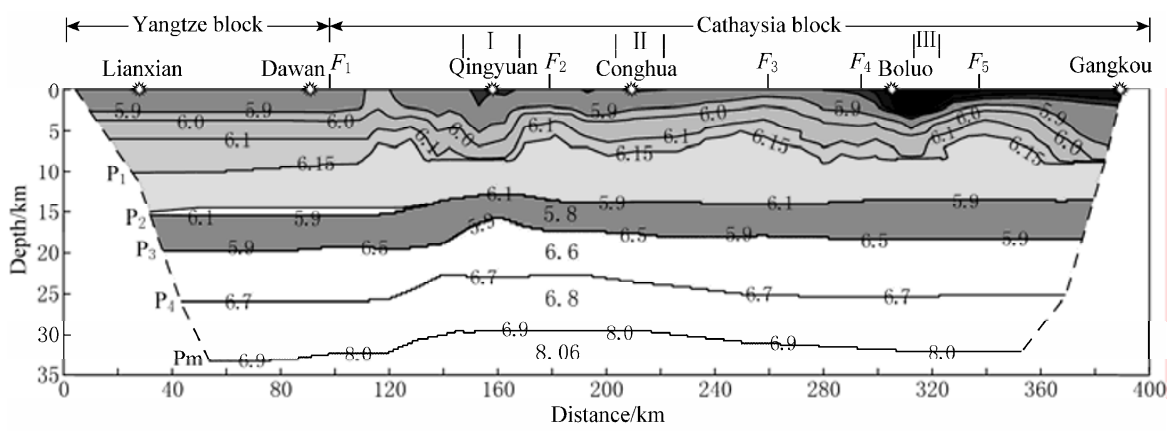

Figure 3 The velocity model including the upper crust, middle crust, lower crust, Moho discontinuity and uppermost mantle (Zhang and Wang, 2007). Isolines of seismic velocity, given in $\mathrm{km} / \mathrm{s}$, emphasize different structures. The lower velocity layer at the bottom of middle crust is constrained by reflective events $\mathrm{P}_{2}$ and $\mathrm{P}_{3}$. The positions of the major active faults are shown on the surface where they intersect the profile. I, II and III separately denote the Minzhong depression, Lianshan depression and Huiyuan basin, same as in Figure 4.

In the experiment, we extend the crustal depth range ( $0 \mathrm{~km}$ at the surface and $40 \mathrm{~km}$ at the Moho) to the depth of $50 \mathrm{~km}$. In this depth expansion, we assume the P-wave velocity to be homogeneous under the Moho or at the uppermost of mantle. In these experiments, we divide the geometry and P-wave velocity of the crust/upper mantle 
model into $1 \mathrm{~km} \times 1 \mathrm{~km}$ nodes. Then, we obtain the reflection image of the crust and upper mantle from the wide-angle seismic profile (Figure 4)

From Figures 3 and 4, we can see that there are two strong amplitude reflections: one with depth range of about $20 \mathrm{~km}$ (seismic reflection from the bottom of the upper crust, one corresponds to the bottom of the lower velocity layer), and another one with depth range of about 33-35 km (seismic reflection from Moho). Beneath the Yangtze block (at the north side of the fault $F_{1}$, top panel of Figures 3 and 4), the upper reflections are very strong and laterally continuous, compared with relatively weak, and not very laterally continuous reflections beneath the Cathaysia block (south to the fault $F_{1}$, top panel of Figures 3 and 4). For the reflections underlying Moho, we can also find the difference between the Yangtze and Cathaysia blocks, where seismic reflections are well-developed under the segment $100 \mathrm{~km}$-to-200 $\mathrm{km}$ of the profile, and relatively weak and nearly transparent under the south segment of the profile. The above mentioned features may suggest the Wuchuan-Sihui fault $\left(F_{1}\right.$, Figure 4$)$ is a south-trending crustal scale fault.

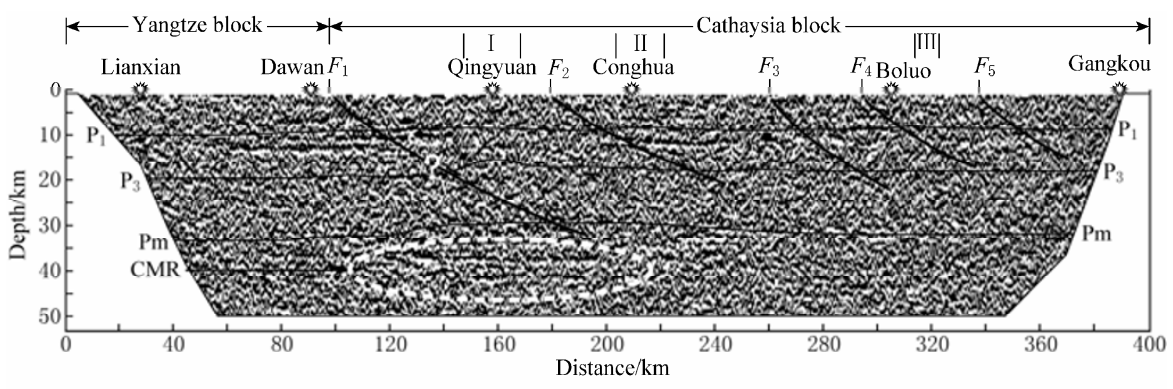

Figure 4 The crustal wide-angle reflection structure with the crustal P-wave velocity model from prestack migration on the wide-angle dataset along the Lianxian-Gangkou profile. CMR denotes the clustering Moho wide-angle reflections in the area bounded by white dashed ellipse.

\section{Discussion and conclusions}

\subsection{Crustal boundary between Yangtze and Cathay- sia blocks}

From our crustal wide-angle seismic reflection images, we can find different pattern of seismic reflection strengths for the Yangtze and Cathaysia blocks (Figure 4). The crustal contact relationship between the Yangtze and Cathaysia blocks suggests the Wuchuan-Sihui fault is the boundary between them. This is consistent with the crustal P-wave velocity structure (Yin et al, 1999; Zhang and Wang, 2007). The fault extends from the surface of the W-S fault to the Moho, which is evidenced by a series of Pn refracted events from Moho (Zhang and Wang, 2007) and is also supported by geochemical studies (Wang et al, 2003). Geochemistry studies show that Mafic rocks west of the Chenzhou-Linwu fault (the northward extension of Wuchuan-Sihui fault, Figure 1) commonly display an enriched mantle 1 (EMI)-like isotopic affinity marked by relatively low $\mathrm{Sr} 87 / \mathrm{Sr} 86$ ratio, light rare Earth element (LREE) enrichment and high ratios of large ion lithosphere element (LILE) to high field strength element) (HFSE). In contrast, mafic rocks to the east of the fault suggest a prevalent EMII-like isotopic signature with significantly higher $\mathrm{Sr} 87 / \mathrm{Sr} 86$ and relatively low LILE/HFSE ratios (Wang et al, 2003). This indicates that Mesozoic mafic rocks around the Chenzhou-Linwu-Wuchuan-Sihui fault have a distinct affinity to enrich lithospheric mantle and tectonic histories. The spatial variation of EMI-EMII-like signatures within Mesozoic mafic rocks around the Wuchuan-Sihui fault, the westward verging early Mesozoic fold and thrust belt and important multi-metal mineralization may shed some light on the nature of the lithospheric boundary between the Yangtze and Cathaysia blocks (Gilder et al, 1996; Wang et al, 2003).

\subsection{A cluster of Moho reflections: Seismic signature of crust/mantle interaction from lithosphere exten-} sion?

On our crustal wide-angle seismic section, we can find there is a cluster of well-developed reflections of Moho (Figure 4), which probably comes from alternative thin layers. Zhang and Wang (2007) found there are multiple refracted Pn-phases recorded after the Pm arrivals for the shots Dawan and Conghua. The variability and complexity of the Pn events could be due to mantle topography that produces the irregular scattering from the Moho interface (Zhang et al, 2000) or stochastic structure underlying Moho (Poppeliers and Levander, 2004). Therefore, there should be a complicate topog- 
raphy presented in the crust-mantle boundary, if there is an abrupt velocity discontinuity, and otherwise a transitional zone enhanced by a strong velocity gradient (Christensen and Mooney, 1995; Zhang et al, 2000).

The cluster of Moho reflections on our crustal wide-angle reflection section may be seismic signature of the crust/mantle interaction by lithosphere extension. The inference is supported by geochemistry studies on the $\sim 1300 \mathrm{~km}$ southeast-northwest profile from coastal South China to Longmenshan ( $\mathrm{Li}$ and Li, 2007). Li and Li (2007) reported the evidence for a sweeping orogeny that migrated from coastal South China $\sim 1300 \mathrm{~km}$ into the continental interior, followed first by the development of a broad intra-continental basin in the wake of migrating orogeny, and then by widespread anorogenic magmatism and continental scale uplift and extension all within an $\sim 100 \mathrm{Ma}$ interval (e.g., Wang et al, 2006). The inference can be indirectly supported by the crustal composition model along Tunxi-Wenzhou profile in the southeastern China, where uniform distribution of about 5 -km-thick basalt presents at the bottom of middle crust (Zhang et al, 2008). All these geophysical (Yuan et al, 1989; Wei et al, 1990; Yin et al, 1999; Zhang and Wang, 2007; Zhang et al, 2000, 2005, 2008, 2009; Gao et al, 2009) and geochemistry (Li et al, 1989; Xu et al, 1993; Faure, 1996; Gilder et al, 1996; Li et al, 2000; Wang et al, 2003; Li and Li, 2007) evidences imply large-scale lithosphere extension in South China.

We made our interpretation of the NW-SE wide-angle seismic profile from Lianxian to Gangkou in South China, and presented the crustal wide-angle seismic reflection images. In the crust, there are two bands with predominant seismic reflections within crust: they correspond to the bottom of upper crust and the discontinuity between crust and upper mantle. Our results reveal the different crustal wide-angle reflection pattern beneath the Yangtze and Cathaysia blocks with the Wuchuan-Sihui fault as the crustal boundary between them, and find there are a cluster of Moho reflections as seismic signature of crust/mantle interaction from lithosphere extension.

Acknowledgements This project was supported by the Chinese Academy of Sciences (KZCX2-YW-132) and the National Natural Sciences Foundation of China (40721003, 40830315). We are indebted to Professor Zhouxun Yin, Dr. Zhiming Bai, Tao Xu, and others who gracefully supplied us geophysical information and who did the seismic data acquisition of the ex-Institute of
Geophysics, CAS, and to Professors Xiangru Kong and Yafen Yan for their constructive comments and suggestions. We also thank the comments from two anonymous reviewers for improvement of the paper.

\section{References}

Angelier J (1990). Inversion of field data in fault tectonics to obtain the regional stress?III. A new rapid direct inversion method by analytical means. Geophys J Int 103: 363-376.

Avendonk Harm J A Van (2004). Slowness-weighted diffraction stack for migrating wide-angle seismic data in laterally varying media. Geophysics 69(4): $1046-1052$.

Braitenberg C, Wienecke S and Wang Y (2006). Basement structures from satellite-derived gravity field: South China Sea ridge. J Geophys Res 111: B05407, doi:10.1029/2005JB003938.

Charvet J, Shu L S, Shi Y S, Guo L Z and Faure M (1996). The building of south China: collision of Yangzi and Cathaysia blocks, problems and tentative answers. J Southeast Asian Earth Sci 13: 223-235.

Chen J F and Jahn B M (1998). Crustal evolution of south-eastern China: Nd and $\mathrm{Sr}$ isotopic evidence. Tectonophysics 284: 101-133.

Christensen N I and Mooney W D (1995). Seismic velocity structure and composition of the continental crust: A global view. J Geophys Res 100: 9 761-9 788 .

Faure M (1996). Extensional tectonics within a subduction-type orogen. The case study of the Wugongshan dome (Jiangxi Province, southeastern China). Tectonophysics 263: 77-106.

Gao Y, Wu J, Cai J A, Shi Y T, Lin S, Bao T and Li Z N (2009). Shear-wave splitting in the southeast of Cathaysia block, South China. Journal of Seismology 13(2): 265-275.

Gilder S A, Gill J and Coe R S (1996). Isotopic and Paleo-magnetic constraints on the Mesozoic tectonic evolution of south China. J Geophys Res 107(B7): 16 137-16 154 .

Grabau A W (1924). Migration of geosynclines. Geol Soc China Bull 3: 207-349.

Guangdong Bureau of Geology and Mineral Resources (1988). Regional Geology Survey in Guangdong Province. Geological Publishing House, Beijing, 721-733 (in Chinese).

Guo L Z, Shi Y S and Ma R S (1983). On the formation and evolution of the Mesozoic-Cenozoic active continental margin and island arc tectonics of the western Pacific Ocean. Acta Geol Sin 1: 11-21.

Holloway N (1982). North Palawan block, Philippines: its relation to the Asian mainland and role in evolution of South China Sea. Am Assoc Petrol Geol Bull 66: $1355-1383$.

Hou Q L and Li J L (1993). A preliminary study on the foreland fold and thrust belt, southwest Fujian. In: Li J L ed. Lithospheric Structure and Geological Evolution of Southeastern Continent. Metallurgical Publishing House, Beijing, 264 (in Chinese).

Hsü K J, Sun S, Li J L, Chen H H, Pen H P and Sengör A M C (1988). Mesozoic overthrust tectonics in south China. Geology 16: 418-421.

Hsü K J, Li J L, Chen H H, Wang Q C, Sun S and Sengör A M C (1990). Tectonics of South China: key to understanding west Pacific geology. Tectonophysics 183: 9-39.

Huang T K ed (1980). Tectonic Evolution of China: Explanatory Notes for 1:4 000000 Tectonic Map of China. Science Press, Beijing, 124 (in Chinese).

Jahn B M, Martineau F, Peucat J J and Cornichet J (1986). Geochronology of the Tananao Schist complex, Taiwan. Tectonophysics 125: 103-124.

Jahn B M, Zhou X H and Li J L (1990). Formation and tectonic evolution of Southeastern China and Taiwan: isotopic and geochemical constraints. Tectonophysics 183: 145-160.

Lafond C F and Levander A (1995). Migration of wide-aperture onshoreoffshore seismic data, central California: Seismic images of late stage subduction. J Geophys Res 100(B11): 22 231-22 243.

Li J L ed (1992). Study on the Texture and Evolution of the Oceanic and Continental Lithosphere in Southeastern China. China Science and Technology Press, Beijing, 267-277 (in Chinese). 
Li J L, Sun S, Hsü K J, Chen H H, Peng H P and Wang Q C (1989). New evidence about the evolution of the South Cathaysia Orogenic Belt. Sci Geol Sin 3: 217-225.

Li X and McCulloch M (1996). Secular variation in the Nd isotopic composition of Neoproterozoic sediments from the southern margin of the Yangtze block: evidence for a Proterozoic continental collision in southeast China. Precamb Res 76: 67-76.

Li X, Sun M, Wei G J, Liu Y, Lee C Y and Malpas J (2000). Geochemical and $\mathrm{Sm}-\mathrm{Nd}$ isotopic study of amphibolites in the Cathaysia Block, southeastern China: evidence for an extremely depleted mantle in the Paleoproterozoic. Precamb Res 102: 251-262.

Li Z X and Li X H (2007). Formation of the 1300-km-wide intracontinental orogen and postorogenic magmatic province in Mesozoic South China: A flat-slab subduction model. Geology 35(2): 179-182, doi: 10.1130/G23193A.

Martin H, Bonin B, Capdevial R, Jahn B M, Lameyre J and Wang Y (1994). The Kuiqi peralkaline granitic complex (SE China): Petrology and geochemistry. J Petrol 35: 983-1 015.

Milkereit B (1987). Migration of noisy crustal seismic data. J Geophys Res 92 : $7916-7930$.

Phinney R A and Jurdy D M (1979). Seismic imaging of deep crust. Geophysics 44: $1637-1660$.

Poppeliers C and Levander A (2004). Estimation of vertical stochastic scale parameters in the Earth's crystalline crust from seismic reflection data. Geophys Res Lett 31: L13607, doi:10.1029/2004GL019538.

Qiu Y, Gao S, McNaughton N, Groves D and Ling W (2000). First evidence of $>3.2 \mathrm{Ga}$ continental crust in the Yangtze craton of South China and its implications for Archean crustal evolution and Phanerozoic tectonics. Geology 28: 11-14.

Ren J S, Chen T Y, Niu B G, Liu Z G and Liu F R (1990). Tectonic Evolution of the Continental Lithosphere and Metallogeny in Eastern China and Adjacent Areas. Science Press, Beijing, 1-205 (in Chinese).

Rodgers J (1989). Comments on Mesozoic overthrust tectonics in south China. Geology 17: 671-672.

Rowley D B, Ziegler A M and Nie G (1989). Comment on Mesozoic overthrust tectonics in south China. Geology 17: 394-396.

Shui T (1988). Tectonic framework of the continental basement of southeast China. Science in China (Series B) 31(7): 885-896.

Wang E K and Liu C (1992). Is the Cathaysia a unified block? Geology of collisional orogenic belts in Early Mesozoic in Fujian and Guangdong. In: Li J L ed. Study on the Texture and Evolution of the Oceanic and Continental Lithosphere in Southeastern China. China Science and Technology Press, Beijing, 96-105 (in Chinese).

Wang Q, Wyman D A, Xü J F, Zhao Z H, Jian P, Xiong X L, Bao Z W, Li C F and Bai Z H (2006). Petrogenesis of Cretaceous adakitic and shoshonitic igneous rocks in the Luzong area, Anhui Province (eastern China): Implications for geodynamics and $\mathrm{Cu}-\mathrm{Au}$ mineralization. Lithos 89: 424-446, doi: 10.1016/j.lithos.2005.12.010.

Wang Y J, Fan W, Guo F, Peng T and Li C (2003). Geochemistry of Mesozoic mafic rocks adjacent to the Chenzhou-Linwu fault, south China: implications for the lithospheric boundary between the Yangtze and Cathaysia blocks. Int Geol Rev 45: 263-286.
Wei S, Teng J, Wang Q and Zhu Z (1990). Crust and Mantle Structure in the East China. Science Press, Beijing, 1-47 (in Chinese).

Xu S T, Sun S, Li J L, Jiang L L, Chen G B and Shi Y H (1993). Lantian structural window. Sci Geol Sin 2: 105-116.

Yang Z Y, Chen Y Q and Wang H Z (1986). The Geology of China. Clarendon, Oxford, 303.

Yin A and Nie S Y (1993). An indentation model for the north and south China collision and the Tan-Lu and Honam fault systems, Eastern Asia. Tectonics 4: 801-813.

Yin Z X, Lai M H, Xiong S B, Liu H B, Teng J W and Kong X R (1999). Crustal structure and velocity distribution from deep seismic sounding along the profile of Lianxian-Boluo-Gangkou in south China. Chinese $J$ Geophysics 42(3): 383-392 (in Chinese with English abstract).

Yuan X C, Zuo Y, Cai X L and Zhu J S (1989). The structure of the lithosphere and the geophysics in the South China Plate. In: Editorial Board of Chinese Journal of Geophysics eds. Progress on Geophysics in China in the 1980s. China Science and Technology Press, Beijing, 243-249 (in Chinese and with English abstract).

Zeng H, Zhang Q, Li Y and Liu J (1997). Crustal structure inferred from gravity anomalies in South China. Tectonophysics 283: 189-203.

Zhang L G, Wang K F, Chen Z S, Liu J X, Yu G X, Wu K L and Lan J Y (1994). On Cathaysia: Evidence from lead isotope study. Geol Rev 3: 200-208 (in Chinese).

Zhang Z J, Wang G, Teng J and Klemperer S (2000). CDP mapping to obtain the fine structure of crust and upper mantle: an example in the Southeastern China. Phys Earth Planet Inter 122: 131-144.

Zhang Z J, Qin Y L, Chen Y, Zhang C Y, Sun S X, Zhao B, Liu Y F and Liu Z $\mathrm{K}$ (2004). Reconstruction of the semblance section for the crust and mantle reflection structure by wide-angle reflection seismic data. Chinese $J$ Geophys 47(3): 469-474.

Zhang Z J, Badal J, Li Y, Chen Y, Yang L and Teng J (2005). Crust-upper mantle seismic velocity structure across Southeastern China. Tectonophysics 395: 137-157.

Zhang Z J and Wang Y H (2007). Crustal structure and contact relationship revealed from deep seismic sounding data in South China. Physics Earth Planet Inter 165: 114-126.

Zhang Z J, Zhang X and Badal J (2008). Composition of the crust beneath southeastern China derived from an integrated geophysical data set. $J$ Geophys Res 113: B04417, doi:10.1029/2006JB0.

Zhang Z J, Teng J W, Badal J and Liu E R (2009). Construction of regional and local seismic anisotropic structures from wide-angle seismic data: crustal deformation in the southeast of China. Journal of Seismology 13(2) 241-252, doi:10.1007/s10950-008-9124-0.

Zhang Z M, Liou J G and Coleman R G (1984). An outline of the plate tectonics of China. Geol Soc Am Bull 95: 295-312.

Zhou X and Li W (2000). Origin of Late Mesozoic igneous rocks in Southeastern China: implications for lithospheric subduction and underplating of mafic magmas. Tectonophysics 326: 269-287. 